\title{
Ephemeral grounding as a signal of ice-shelf change
}

\author{
Marjorie Sahmeltz, ${ }^{1}$ Eric Rignot, ${ }^{1}$ Douglas R. MagAyeal ${ }^{2}$ \\ ${ }^{1}$ Jet Propulsion Laboratory, California Institute of Technology, 4800 Oak Grove Drive, Pasadena, California 91109-8099, U.S.A. \\ ${ }^{2}$ Department of Geophysical Sciences, University of Chicago, Chicago, Illinois 60637, U.S.A.
}

\begin{abstract}
Interferometric synthetic aperture radar (InSAR) observations of iceshelf tidal deformation reveal the wide transition between grounded and floating ice as well as local areas where the ice shelf is only grounded at low tide, a condition that we call ephemeral grounding. Ephemeral grounding creates a subtle, local disturbance on the vertical motion field of the ice-shelf surface in response to changes in oceanic tide which is detected with millimetric precision using InSAR. These ice-shelf features are, however, not expected to produce a noticeable disturbance on the ice-shelf velocity field. To illustrate the influence of ephemeral grounding on ice-shelf creep flow, we use a finite-element model in which ephemeral grounding is incorporated through a variable basal friction coefficient. The results show that while ice rises (permanently grounded areas) have a pronounced influence on the ice-shelf velocity field, areas of ephemeral grounding have a vanishingly small influence. What is thus of most interest is the capacity for observations of ephemeral grounding to reveal subtle changes in ice-shelf thickness over time. We discuss an example in the Thwaites Glacier area, West Antarctica, where multi-year data show how ice rises become ephemeral grounding and subsequently disappear. This result is consistent with the grounding-line retreat and ice thinning of Thwaites Glacier.
\end{abstract}

\section{INTRODUGTION}

Ice-shelf flow is resisted by ice rises, ice rumples and by shear friction along the side margins (e.g. Thomas, 1973). For ice rises, where flow is diverted around the perimeter of grounded ice, and ice rumples, where flow is diverted over the grounded region, resistance occurs at all phases of the ocean tide (i.e. at high tide as well as at low tide).

In this study, we present observational evidence of a new kind of ice rumple in which grounding occurs only during low tide (i.e. the ice shelf floats freely at high tide), and where the associated resistance must therefore vary with the tidal cycle. We call this new ice-shelf feature an ephemeral grounding zone and use differential interferometric synthetic aperture radar (InSAR) data to display various examples found in the Antarctic. Differential InSAR is a technique which combines two interferograms spanning the same time interval and acquired from the same orbit configuration, as is discussed in more detail elsewhere (e.g. Rignot and others, 2000). One of the hallmark features of differential interferometry is its ability to display with great precision and spatial clarity areas where the ice shelf is grounded (Rignot, 1998b). Our objectives are to determine (a) how significantly these features contribute to the overall resistance of ice-shelf flow and (b) whether changes in ephemeral grounding over time may be used to monitor iceshelf thickness and grounding-line location.

The creep flow of an ice shelf and its tidal deformation are both measured on a single SAR interferogram because InSAR measures the overall displacement of the reflecting surface in the radar line of sight. The line of sight is $23^{\circ}$ away from the vertical direction in the case of European Remotesensing Satellites 1 and 2 (ERS-1 and -2). Assuming that the ice-shelf flow is continuous and steady with time, a combination of two interferograms spanning the same time interval permits the elimination of the signal associated with creep deformation. The residual measurement contains only the change in vertical displacement of the ice-shelf surface in response to changes in oceanic tides (Rignot, 1996). The converse, which is to eliminate the tidal motion from the ice-shelf velocity field, is possible but more difficult to achieve, especially with the same degree of precision, because it requires a precise knowledge of oceanic tides underneath the ice shelf (which is typically not available) or the examination of a longer time period of creep-flow deformation. As a result, the effect of ephemeral grounding on the tidal regime of an ice shelf is detected with great precision in ERS interferograms, while the same data procure little information on its influence on ice-shelf creep rates.

To address the importance of the influence of ephemeral grounding on ice-shelf flow, we use a finite-element model designed to simulate ice-shelf flow in realistic geometries. The model design and application is similar to that described by Hulbe and others (1998). Model simulations of ephemeral grounding at the mouth of Rutford Ice Stream and on the ice shelf in front of Pine Island Glacier, both areas of West Antarctica, are used to quantitatively estimate the role of ephemeral grounding in resistance to ice-shelf flow.

The usefulness of ephemeral grounding as a means of monitoring subtle changes in ice-shelf thickness is evaluated for two examples. First, we present a time series of InSAR observations of the grounding zone of Thwaites Glacier, West Antarctica, collected in 1992, 1994 and 1996. This glacier appears to be in a state of retreat (Rignot, in press). Second, we discuss the case of Rutford Ice Stream for which knowledge of oceanic tides (personal communication from D. G. Vaughan, 1997) is combined with InSAR results to infer the water-column thickness underneath areas of ephemeral grounding. 


\section{STUDY AREAS (GLAGIOLOGIGAL SETTING)}

Differential InSAR enables grounded parts of an ice shelf to be detected with spectacular precision $(\mathrm{mm})$ compared to what could be achieved in the field even with modern technology ( $\mathrm{cm}$ precision with global positioning system traverses (e.g. Rignot, 1998b)). Areas of ephemeral grounding, as defined earlier, are observed in numerous interferograms of Antarctic ice shelves. In this paper, we focus our discussion on three selected areas of ephemeral grounding which cover a spectrum of ice-shelf morphology and flow style. The location and orientation of the InSAR imagery used in this study is displayed in Figure 1.

Rutford Ice Stream (Fig. 1) flows into the Ronne Ice Shelf from its extreme inland boundary, approximately $1000 \mathrm{~km}$ from the ice front. Ice-shelf flow in the grounding zone of this glacier is thus highly constrained by the coastal geometry and the presence of ice rises downstream. The $30 \mathrm{~km}$ wide ice stream enters the ice shelf with a velocity of about $0.4 \mathrm{~km} \mathrm{a}^{-1}$ (Frolich and Doake, 1988) and an ice thickness of about $1650 \mathrm{~m}$ (Smith and Doake, 1994). Seismic surveys conducted in the region suggest that the seabed underneath the floating portion of Rutford Ice Stream is hummocky (Smith and Doake, 1994), and the tidal range in the region is large (e.g. Robertson and others, 1998). The hummocky bottom and large tidal range combine to produce ephemeral grounding downstream of the permanent (constrained by a bedrock knoll) grounding line of the ice stream.

In contrast to the grounding zone of Rutford Ice Stream, Pine Island Glacier and Thwaites Glacier (Fig. 1) flow into

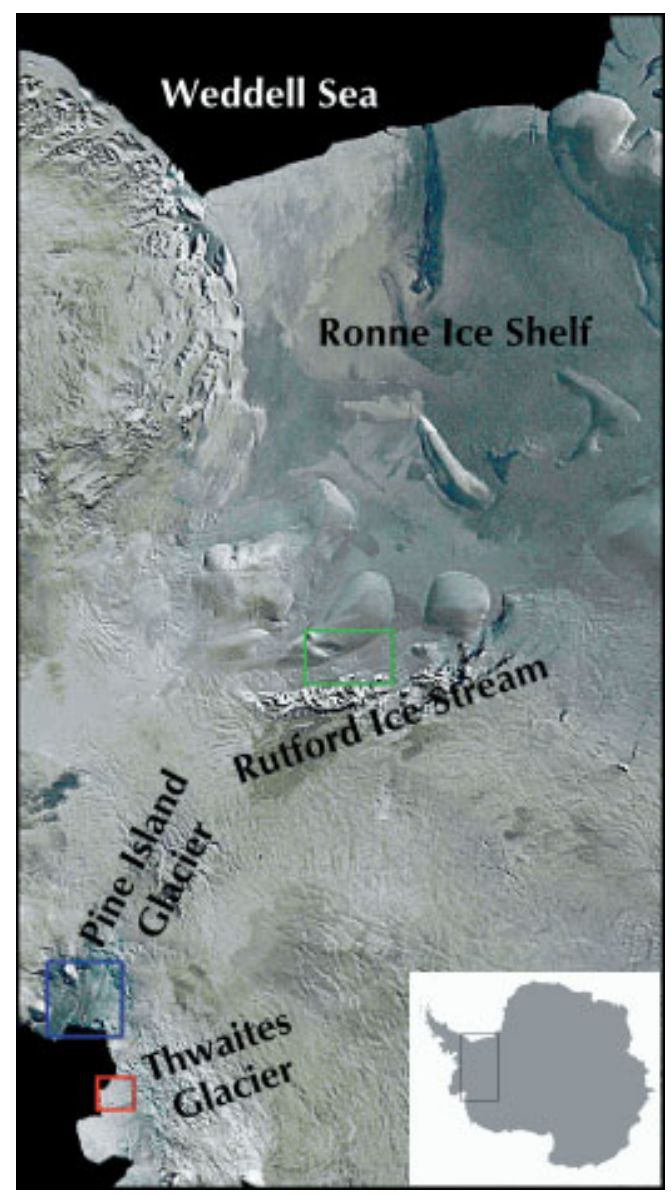

Fig. 1. Location map indicating the studied areas: Rutford Ice Stream, Pine Island Glacier and Thwaites Glacier, plotted on the United States Geological Survey Advanced Very High Resolution Radiometer mosaic of Antarctica (Merson, 1989). short, virtually unconstrained ice shelves of limited size. Ephemeral grounding areas are also found in these ice regions, which we deem to be distinct in both morphology and flow style from that of the Rutford Ice Stream region.

Pine Island Glacier is a fast-moving outlet glacier which flows into the Amundsen sea at about $2.4 \mathrm{~km} \mathrm{a}^{-1}$ (e.g. Ferrigno and others, 1998). It enters a small ice shelf $70 \mathrm{~km}$ long by $40 \mathrm{~km}$ wide that appears to provide some buttressing influence on the flow at the grounding line (personal communication from T. K. Dupont and M. Schmeltz, 1999). The ice-shelf thickness decreases from about $1400 \mathrm{~m}$ at the grounding line to $400 \mathrm{~m}$ at the calving front (Crabtree and Doake, 1982). That extraordinary amount of ice thinning has been attributed to basal melting (Jenkins and others, 1997; Rignot, 1998a). The flow of Pine Island Glacier appears to be impeded by several small-size ice rises, mainly located near the ice front (Rignot, 1998a).

Thwaites Glacier enters the Amundsen Sea directly west of Pine Island Glacier. Flowing at approximately $3 \mathrm{~km} \mathrm{a}^{-1}$, the ice tongue of Thwaites Glacier ranks among the fastest moving ice masses in Antarctica. The ice-shelf section of interest to us, located east of the main fast-moving ice tongue, is the smallest ice shelf discussed in this study. About $40 \mathrm{~km}$ by $30 \mathrm{~km}$ in size, it flows at about $0.5 \mathrm{~km} \mathrm{a}^{-1}$ (interferometric estimation) and abuts a large, prominent ice rise.

\section{INTERFEROMETRIC OBSERVATIONS}

The fringe pattern observed in a typical SAR interferogram of an ice-shelf region reveals displacements caused by both creep flow and vertical tidal motion of the ice shelf (Hartl and others, 1994). In circumstances where ice-shelf flow is continuous and relatively steady with time, it is possible to eliminate the creep-flow signal using differential interferometry, which is described in detail by Rignot and others (2000). Tide-only interferograms (i.e. double-difference interferograms) reveal narrow bands of elastic tidal flexure surrounding regions of permanent and ephemeral grounding (e.g. Rignot, 1996, 1998a). The nature of this flexure is discussed by Holdsworth $(1969,1977)$.

What is of primary interest in this study is the fringe patterns found in differential interferograms which signify elastic tidal flexure along the coast, around ice rises and around zones of ephemeral grounding. Examples of such fringe-line patterns are shown in Figures 2-5. In those figures, each interferometric fringe, represented by a full color cycle, corresponds to a different number of radians change in interferometric phase. For reference, a $2 \pi$ rad change in phase corresponds to a $31 \mathrm{~mm}$ displacement of the ice-shelf surface in the vertical direction $\left(31 \mathrm{~mm}\right.$ is $\lambda / 2 / \sin \left(23^{\circ}\right)$, where the radar wavelength $\lambda$ is $56 \mathrm{~mm}$ ). The displacement is measured between several epochs and as such does not represent an absolute tidal displacement in reference to mean sea level, but a change in vertical displacement of the ice shelf over a combination of time periods. For more details, we refer to appendix A of Rignot and others (2000).

The important aspect of fringe-pattern analysis is the method by which we distinguish zones of permanent grounding from zones of ephemeral grounding. This task requires that the ocean tide be relatively uniform in both amplitude and phase throughout the region covered by the differential interferometry. Under most circumstances, as indicated by models of sub-ice-shelf tide (e.g. Robertson 


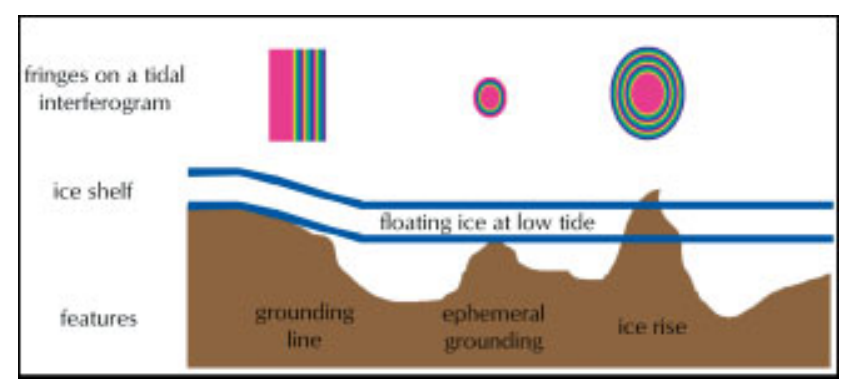

Fig. 2. Cartoon showing the differences between permanent and ephemeral grounding. Ephemeral grounding is distinguished from permanent grounding by whether or not the number of fringes in the "bull'-eye" is less than or equal to the number of fringes which define the grounding line.

and others, 1998), this assumption is valid. The method we use for discrimination is shown schematically in Figure 2. First, we examine the differential interferogram for two generic types of fringe patterns: (a) the closely spaced "bull's-eye" patterns that signify local islands of grounding, and (b) the closely spaced "ribbon" patterns that signify the main grounding line (where the shelf starts to float). Next, we count the number of fringes in all of the examples of the two patterns seen in the differential interferogram. Finally, using the number of fringe lines identified at the main grounding line as the critical reference, we are able to say whether regions of local "island-type" grounding are permanent or ephemeral. Where the fringe count is equal to the critical reference count, permanent grounding is indicated, because the ice is shown to have the same response to tidal uplift as the main grounded ice body. Where the fringe count is less than the critical reference count, ice must have become ungrounded during the tidal cycle, and ephemeral grounding is indicated.

A conceptual explanation of why this method works can be provided succinctly as follows. For the difference in tidalflexure displacement between two pairs of satellite passes to vary from one tidal-flexure zone to another, there must be a difference in the range of tidal motion. This can happen where there is an unusual and unlikely variation in the ocean-tide amplitude, which we reject by assumption (e.g. Robertson and others, 1998); or where a part of the ice shelf rises at high tide, but does not settle fully at low tide because it is grounded.

For the example provided in Figure 2, the grounding line and permanent ice rise both have three fringes. The ephemeral grounding, i.e. grounding which occurs only at low tide, has only one fringe. The fact that the fringe count for the ephemeral grounding zone is less than for either the grounding line or the permanently grounded ice rise distinguishes the ephemeral grounding from the other two cases.

\subsection{Rutford Ice Stream}

The tidal interferogram of Rutford Ice Stream (Fig. 3) combines three separate passes of the ERS-1 satellite, collected at a 3 day time interval in 1992. Two interferograms were constructed by differencing the phase between the second and first passes for one, and the third and second passes for the other. The two interferograms were then differenced to obtain the differential interferogram shown in Figure 3.

Downstream of the grounding line, there is an area where the number of fringes between the center of the presumed ice

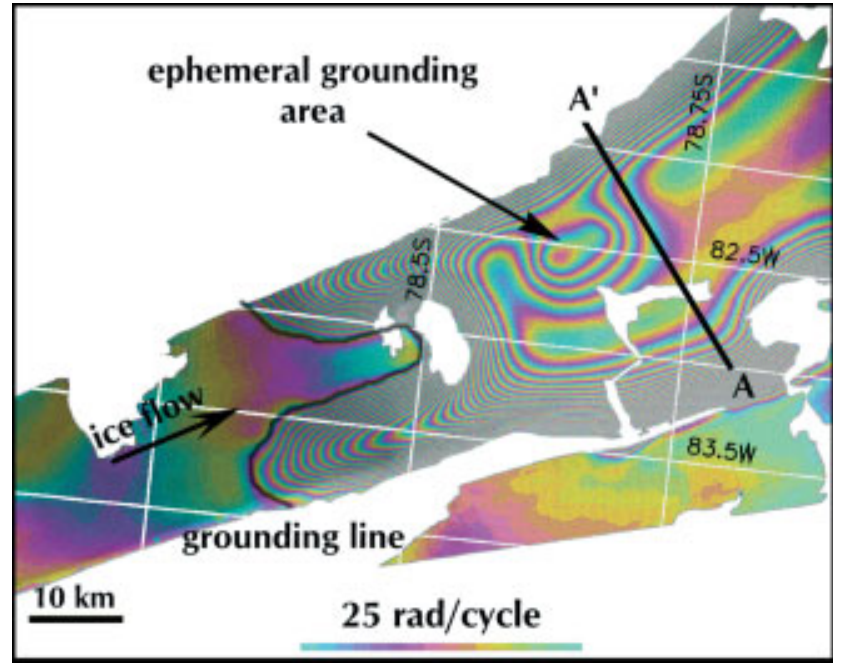

Fig. 3. Tidal interferogram of Rutford Ice Stream in 1992. The area of ephemeral grounding is located at $78.65^{\circ} \mathrm{S}, 82.5^{\circ} \mathrm{W}$. The scale of $25 \mathrm{rad}$ per cycle represents a $123 \mathrm{~mm}$ vertical displacement of the glacier surface induced by tidal motion from blue to blue. The white masked areas denote where phase could not be unwrapped. The cross-section $A A^{\prime}$ is from Smith and Doake (1994, fig. 4). The orientation of the box is the same as in Figure 1.

rise and the ice shelf is less than the number of fringes counted across the grounding line. We count 26 fringes across the grounding line but only four fringes in the bull's-eye pattern. This signifies ephemeral grounding.

Seismic surveys conducted in the area do not reveal an isolated peak at the location of ephemeral grounding on Rutford Ice Stream (Smith and Doake, 1994). The density of InSAR data observations is, however, higher than that of the seismic survey; thus the lack of seismic data indicating a seabed hummock capable of causing ephemeral grounding is not necessarily incompatible with the results of the InSAR data. Furthermore, figure 4 in Smith and Doake (1994) showing the water column and seabed across section $\mathrm{AA}^{\prime}$ ( shown here in Fig. 3) illustrates the rough character of the bed in this region, which would be consistent with ephemeral grounding revealed by the InSAR data.

\subsection{Pine Island Glacier}

The differential interferogram of the small ice shelf in front of Pine Island Glacier is shown in Figure 4. The fringe count across the grounding line is five. Near the ice front, several features have been labelled as ice rises because the bull's-eye patterns are formed with the same number of fringes as across the grounding line. Several examples of ephemeral grounding are also apparent, the most prominent of which is near the grounding line at approximately $75.31^{\circ} \mathrm{S}$, $100.5^{\circ} \mathrm{W}$, as labeled on the figure. The close proximity of this zone to the grounding line suggests a rather flat seabed, so there is a possibility for sea water to infiltrate over a long distance underneath grounded ice at high tide, which is consistent with the identification of an ice plain in this region by Corr and others (2000).

\subsection{Thwaites Glacier}

Ephemeral grounding is also evident on Thwaites Glacier, as shown in a series of three tidal interferograms obtained in 1992, 1994 and 1996 (Fig. 5). Two areas of ephemeral grounding labeled in the 1992 differential interferogram (those near 


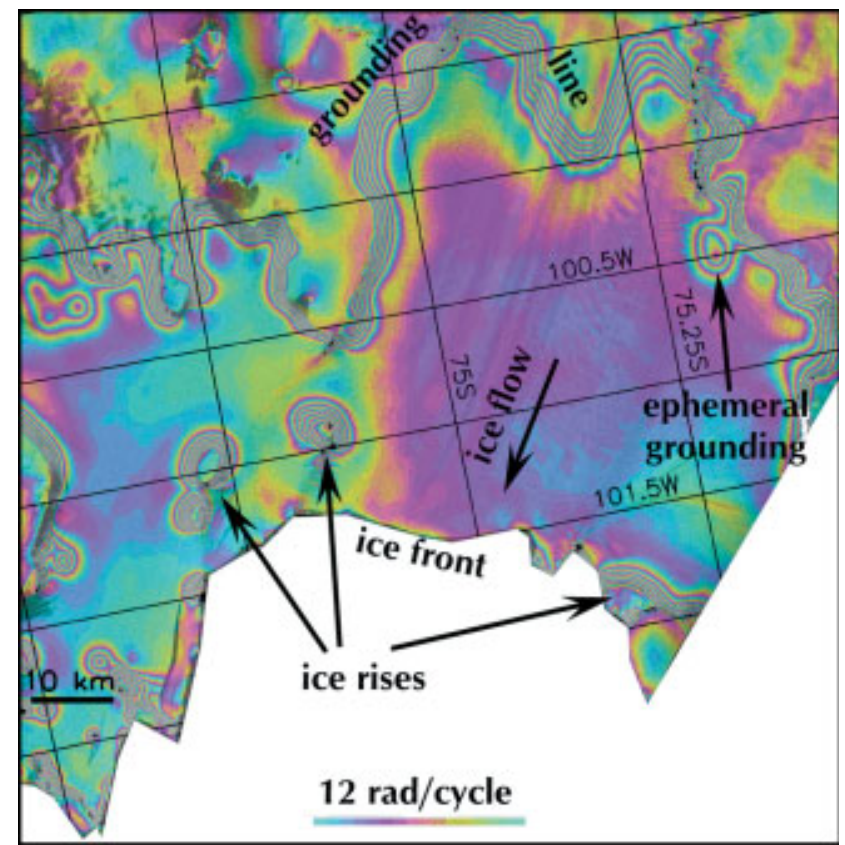

Fig. 4. Tidal interferogram of the ice shelf at the outlet of Pine Island Glacier in 1996. The scale of 12 rad per cycle represents $59.2 \mathrm{~mm}$ vertical displacement. The orientation of the box is the same as in Figure 1.

the grounding line in Figure 5a) deserve particular attention. They are not detected in the 1994 or 1996 differential interferograms. This means that the ice shelf was not able to establish contact with the seabed at low tide in 1994 and 1996, probably because the shelf is thinning.

Another feature seen in the 1992 differential interferogram shows a remarkable evolution. The ice rise located at $75.1^{\circ} \mathrm{S}, 105.25^{\circ} \mathrm{W}$, in the 1992 differential interferogram becomes an area of ephemeral grounding in the 1994 differential interferogram and is no longer visible in the 1996 differential interferogram. In the 1992 interferogram, the number of fringes surrounding the ice rise is the same as across the grounding line (seven fringes). In 1994, we see only a little more than one fringe, whereas eleven are counted across the grounding line. The zone of contact completely disappears in the 1996 interferogram, while we count four to five fringes across the flexure zone.

We interpret the changes in the ice rise and ephemeral grounding zone discussed above as indicating ice-shelf thinning over the period of observation (1992-96). Because the glacier bed is unlikely to be flat, such areas of ephemeral grounding are likely to be present over an area where an ice shelf is thinning. This suggests that the observation of ephemeral grounding could be used to monitor ongoing ice-shelf thickness change.

The ephemeral grounding area in the center of the ice shelf evolves differently from the two examples discussed above. On the 1994 differential interferogram (Fig. 5b) we see a twin bull's-eye pattern where the ice-shelf displacement is of opposite sign compared to other areas of ephemeral grounding (hence the color cycle of the bull's-eye pattern is reversed compared to other areas). In 1992 and 1996, there seems to be only one bull's-eye pattern at this location. This area of ephemeral grounding therefore evolves differently from the others. Since this portion of the ice shelf is influenced by a large ice rise located downstream (numerous compression ridges are seen in the imagery between the ice rise and the zone of ephemeral grounding),
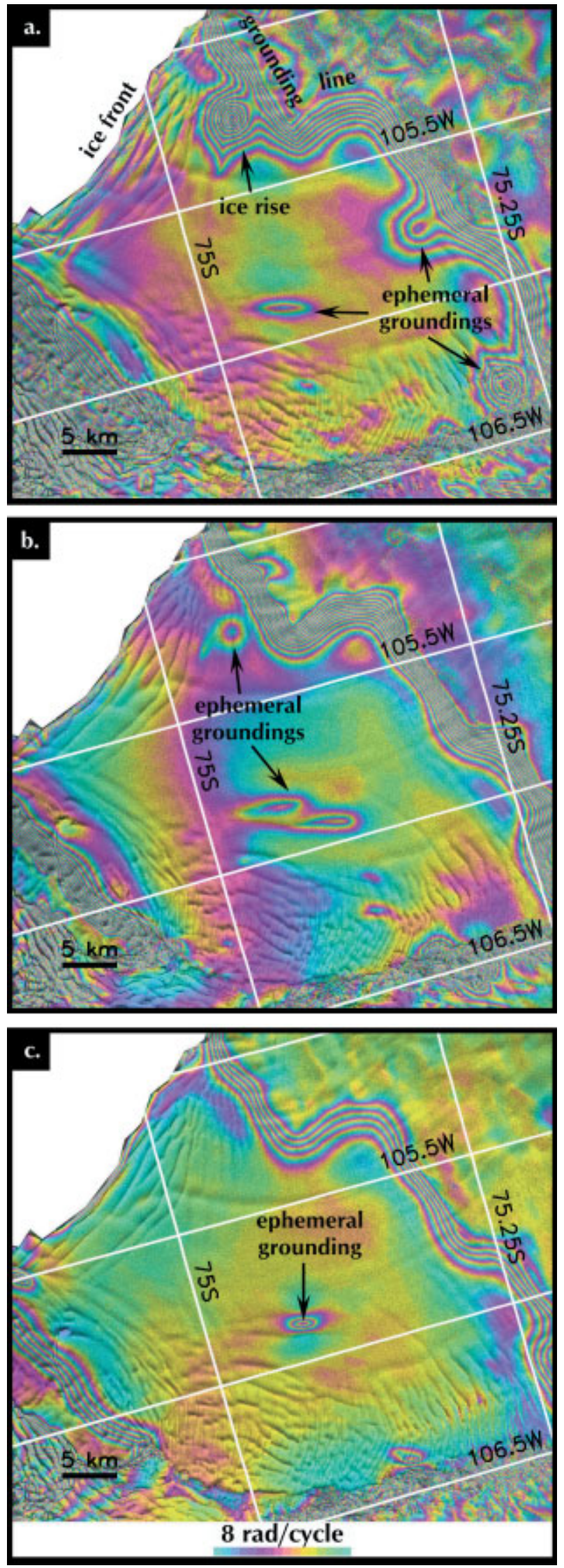

Fig. 5. Tidal interferograms of the ice shelf at the outlet of Thwaites Glacier in (a) 1992, (b) 1994 and (c) 1996. The scale of $8 \mathrm{rad}$ per cycle represents a $39.5 \mathrm{~mm}$ vertical displacement. The orientation of the boxes is the same as in Figure 1.

the ice-shelf thickness is most likely not uniform in this area, which complicates the interaction of the ice-shelf bottom with the sea floor during a tidal cycle, especially as irregularities in ice-shelf thickness are advected downstream. 
Without further knowledge of oceanic tides, ice-shelf thickness and ocean depth, it is not possible to explain the observed evolution of the twin-bull's-eye fringe pattern.

\subsection{Ice-thickness change: example of Rutford Ice Stream}

Ice-thickness changes may also be detected from a combination of tide predictions and a time series of InSAR data. First, we estimate the water-column thickness underneath the ice shelf at one epoch. Second, we differentiate estimates obtained at different epochs to measure the rate of thinning or thickening. We study the case of Rutford Ice Stream for which tidal predictions are available.

As mentioned earlier, the 1992 tidal interferogram of Rutford Ice Stream results from the combination of three passes, which we label $t_{1}, t_{2}$ and $t_{3}$. For these three passes, the oceanic tide, at the location of the ephemeral grounding, is respectively $-1.826,-0.030$ and $-1.204 \mathrm{~m}$, referenced to mean sea level (personal communication from D. G. Vaughan, 1997, reported in Rignot, 1998a, table 2). The differential interferogram shown in Figure 3 is the difference $\left(t_{2}-t_{1}\right)-\left(t_{3}-t_{2}\right)$. We therefore expect to measure a difference in tidal displacement across the grounding zone of $2.97 \mathrm{~m}$ in the radar interferogram. We measure 26 fringes, which corresponds to a $3.2 \mathrm{~m}$ displacement. The difference between the two estimates is within the uncertainty of the tidal predictions $( \pm 10 \mathrm{~cm})$.

The area of ephemeral grounding yields four fringes or a $0.5 \mathrm{~m}$ displacement between the center of the ephemeral grounding and the freely floating ice shelf. The area of ephemeral grounding must have been in contact with the sea floor at the lowest tide, which is $t_{1}$, and not in contact with the sea floor at the highest tide, which is $t_{2}$. Since $\left(t_{1}-t_{3}\right)$ is $>0.5 \mathrm{~m}$, there was no contact at $t_{3}$ either. Hence, the $0.5 \mathrm{~m}$ displacement is the vertical displacement from the lower tide $t_{1}$. The water-column thickness is therefore $\left|t_{1}\right|-0.5$ or $1.33 \mathrm{~m}$ at the location of the ephemeral grounding. If we assume a tidal amplitude of $2 \mathrm{~m}$ (the tidal amplitude must be $>\left|t_{1}\right|$ ), this means that the ice is in contact with the bedrock during less than one-third of a tidal cycle over the area of ephemeral grounding.

A similar calculation was made for the 1996 tidal interferogram of Rutford Ice Stream (Rignot, 1998b). We obtained a mean water-column thickness of $1.42 \mathrm{~m}$ at the location of the ephemeral grounding. The difference between this estimate and the 1992 estimate $(+9 \mathrm{~cm})$ is within the uncertainty of the tidal predictions. We may conclude from this analysis that there is no detectable change in ice thickness on Rutford Ice Stream between 1992 and 1996. This result is consistent with the stable grounding-line position of this glacier, discussed in Rignot (1998b).

\section{MODEL STUDY}

We investigate how ephemeral grounding influences the velocity by simulating the ice-shelf flow at the mouth of Rutford Ice Stream and Pine Island Glacier using a numerical model of ice-shelf stress balance. Thwaites Glacier is not modelled because reliable ice-thickness data are not available in the area. The model used here is described by MacAyeal and others $(1995,1996)$ and has been used in other applications of InSAR interpretation (e.g. Hulbe and others, 1998). A finite-element method is used to solve the "reduced" stressbalance equations appropriate for ice-shelf flow on a mesh of

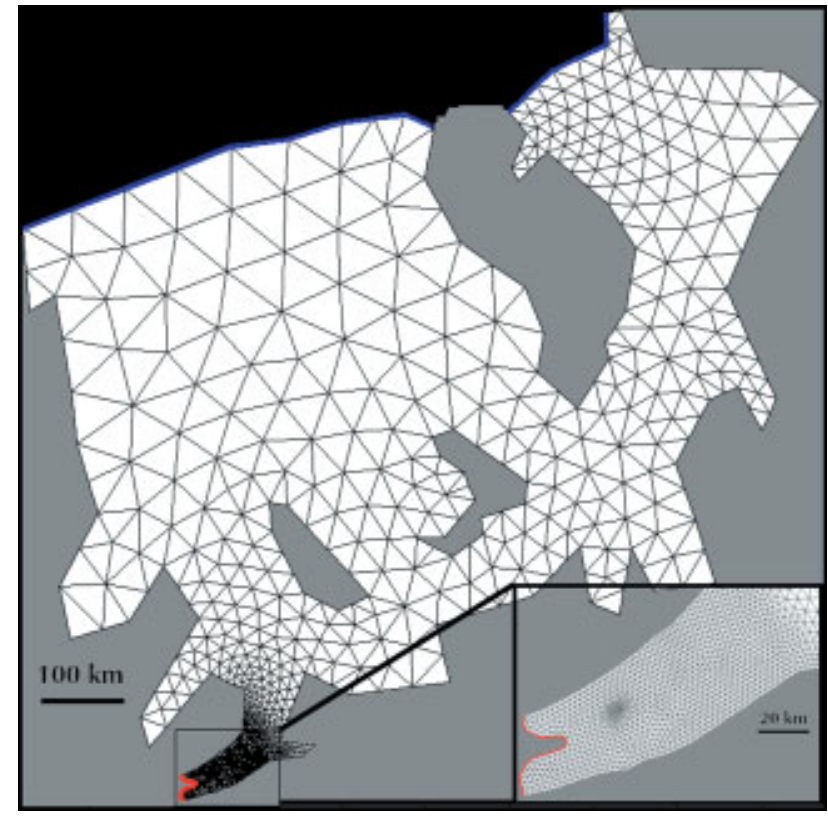

Fig. 6. Model mesh covering the entire Filchner-Ronne Ice Shelf. Rutford Ice Stream is at the bottom center of the mesh. The mesh comprises 3752 elements with 2056 nodes. The inset shows an expanded view of the mesh near the outlet of Rutford Ice Stream, where we use a higher mesh resolution. The projection is polar stereographic. Black areas denote open or sea-icecovered water; gray areas denote grounded ice. The red line identifies the grounding line of Rutford Ice Stream; the blue line identifies the ice-shelf front.

triangular elements covering realistic ice-shelf geometries. Grounded ice upstream of the grounding line is not included in the model domains, and grounded ice downstream of the grounding line is treated through the introduction of variable basal stress as described below.

Figures 6 and 7 show the two model domains of Rutford Ice Stream and Pine Island Glacier. Ice thickness is required as input to the model. For Rutford Ice Stream, we use a constant thickness of $1650 \mathrm{~m}$ (an average from Smith and Doake, 1994). For Pine Island Glacier, we calculate ice thickness from Bamber and Bindschadler's (1997) digital elevation model of Antarctica referenced to mean sea level, assuming an ice shelf in hydrostatic equilibrium.

Both kinematic and dynamic boundary conditions are

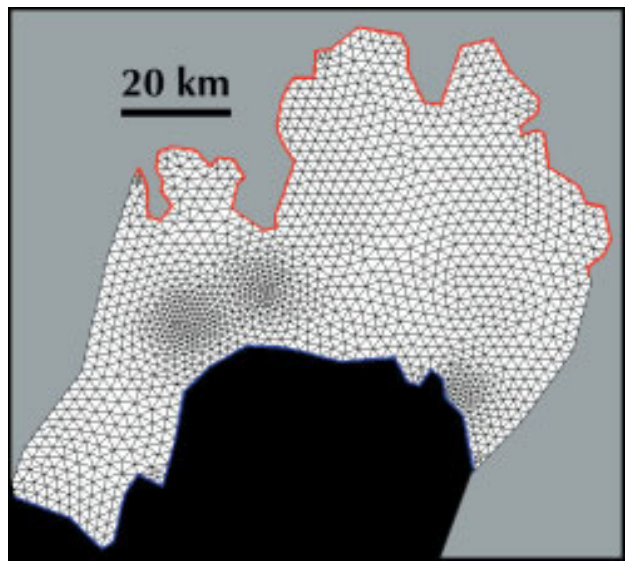

Fig. 7. Model mesh of the ice shelf of Pine Island Glacier. The mesh comprises 2703 elements with 1469 nodes. The projection is polar stereographic. Black areas denote open or sea-ice-covered water; gray areas denote grounded ice. The red line identifies the grounding line; the blue line identifies the ice front. 


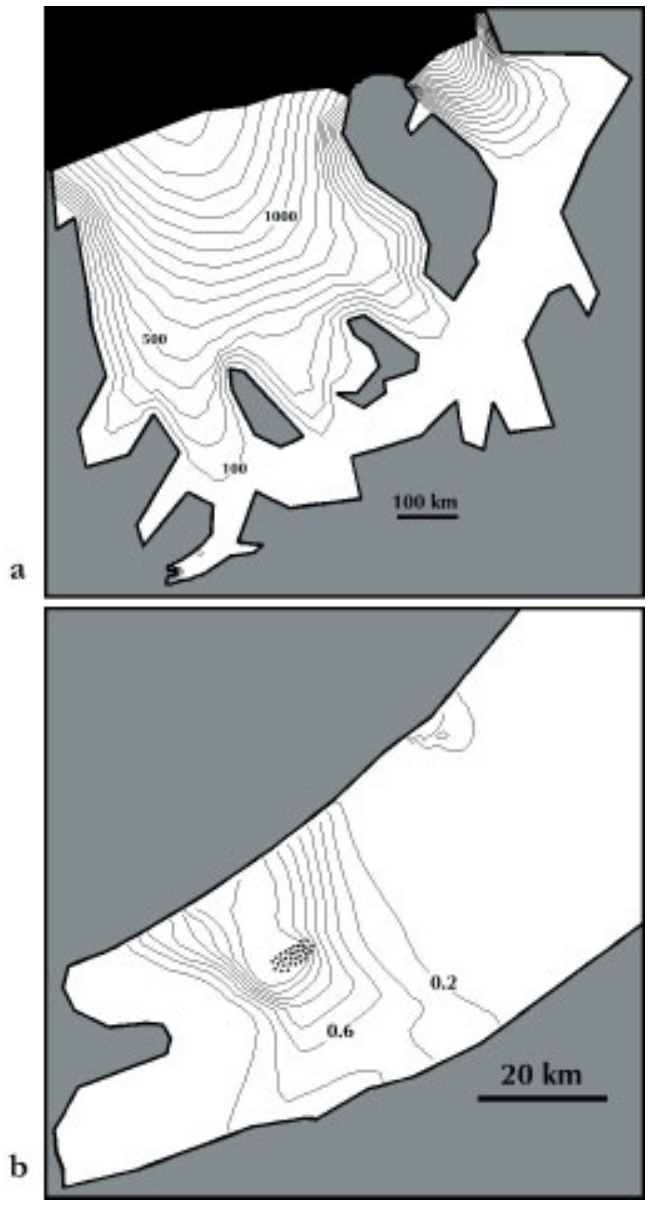

Fig. 8. (a) Modeled velocity of the floating ice downstream of Rutford Ice Stream, including the whole Filchner-Ronne Ice Shelf, with a zero basal friction coefficient (contour interval is $100 \mathrm{~m} \mathrm{a}^{-1}$ ). (b) Percentage difference between model without ephemeral grounding and model with ephemeral grounding, for the region near the outlet of Rutford Ice Stream only (contour interval is $0.2 \%$ ). The dots mark the location of ephemeral grounding.

needed to solve the stress-balance equations. The kinematic boundary condition is the velocity at the model domain boundary. At the glacier grounding line, velocity is prescribed according to InSAR velocity estimates (Rignot 1998a, b). Where the ice shelf flows past grounded ice coasts and around well-established ice rises (e.g. Henry, Korff and Berkner Island on the Ronne Ice Shelf), the velocity is prescribed to be zero, i.e. a no-slip condition. A dynamic boundary condition is also applied at the seaward ice front where ice-shelf flow is resisted by sea-water pressure alone.

Small ice rises in the Pine Island Glacier simulation and ephemeral grounding zones in both simulations are considered in the mesh design and treated by specification of a basal friction coefficient $\beta$ (in $\mathrm{Pa} \mathrm{s} \mathrm{m}^{-1}$ ) at specified mesh elements, independently of the rest of the mesh. This approach allows the ice to potentially flow over the seabed on which it is grounded. While not entirely consistent with the simplifying assumptions of the model equations, this approach represents a logical first step in evaluating the degree of resistance provided by small areas of grounding. The basal stress $\tau_{\mathrm{b}}$ generated by the flow over the seabed is determined by the model, and is given by $\beta \cdot u_{\mathrm{b}}$, where $u_{\mathrm{b}}$ is the ice velocity at the bed (assumed to be the same as the vertically constant ice-shelf velocity). The coefficient $\beta$ is zero in the absence of ice rise or ephemeral grounding, so the basal stress is zero. We

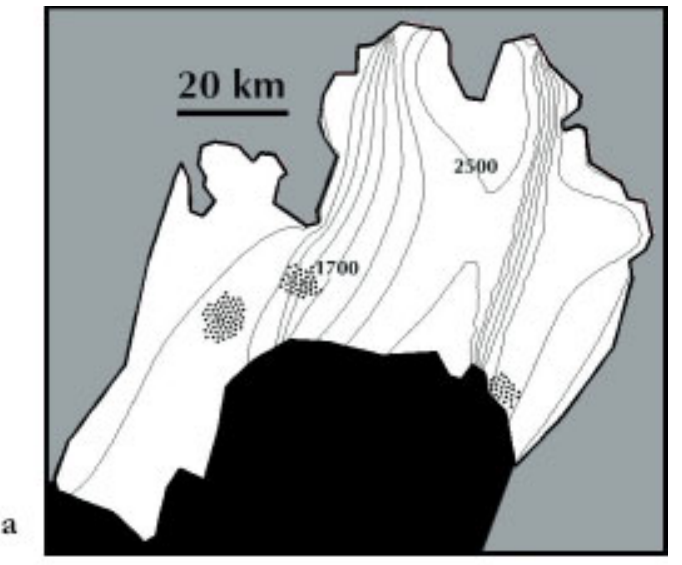

b
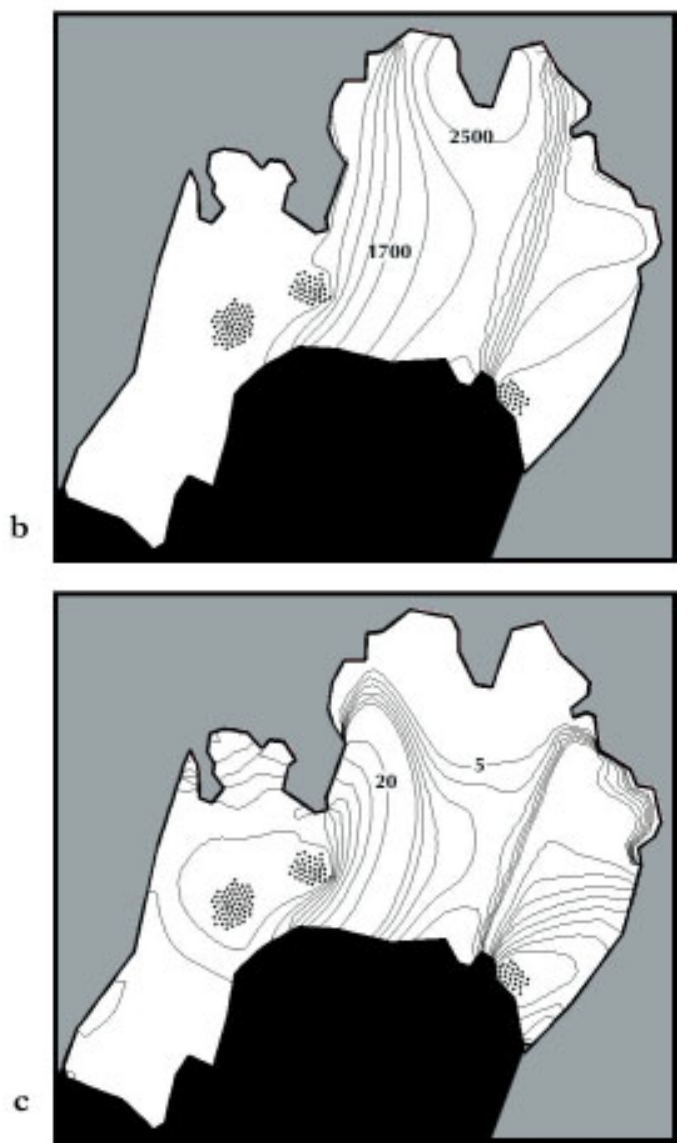

Fig. 9. (a) Modeled velocity of Pine Island Glacier with a zero basalfriction coefficient (no grounding). (b) Modeled velocity with a $\beta$ value equal to $10^{40} \mathrm{~Pa} \mathrm{~m}^{-1}$ (i.e. a value selected to stop flow over the seabed). Contour intervals are $200 \mathrm{~m} \mathrm{a}^{-1}$ from 2500 to 2100, and $400 \mathrm{~m} \mathrm{a}^{-1}$ thereafter. (c) Percentage difference between model without ice rises and model with ice rises (contour interval is $1 \%$ from $5 \%$ to $10 \%$, and $10 \%$ thereafter). The small dots mark the location of the ice rises.

explored a range of $\beta$ values to determine the sensitivity of the ice-shelf flow to increasing seabed contact in ephemeral grounding zones. This range is $10^{9}$ to $10^{10} \mathrm{~Pa} \mathrm{sm}^{-1}$ (as in MacAyeal and others, 1995). To simulate an ice rise in which the ice shelf can no longer flow over the seabed, $\beta$ should be infinite, so in practice we use $\beta=10^{40} \mathrm{~Pa} \mathrm{~s} \mathrm{~m}^{-1}$.

We first simulate ice flow for both Rutford Ice Stream and Pine Island Glacier using a basal friction coefficient of zero on all grounded regions (ice rises and ephemeral grounding). This establishes a reference velocity field which we then compare to the results obtained using different values of $\beta: 10^{10} \mathrm{~Pa} \mathrm{~s} \mathrm{~m}^{-1}$ for the ephemeral grounding zone of Rutford Ice Stream, and $10^{40} \mathrm{~Pa} \mathrm{~s} \mathrm{~m}^{-1}$ for the ice rise in 
Pine Island Bay. The grounding on Rutford Ice Stream occurs during less than one-third of a tidal cycle. Therefore, the mean velocity with grounding is the sum of two-thirds of the reference velocity and one-third of the velocity simulated with $\beta=10^{10} \mathrm{~Pa} \mathrm{~s} \mathrm{~m}^{-1}$.

We assess the influence of ephemeral grounding and small ice rises in the case of Pine Island Glacier by comparing the velocity fields in the $\beta=0$ and $\beta \neq 0$ scenarios.

\section{RESULTS AND DISGUSSION}

The presence of ephemeral grounding downstream of Rutford Ice Stream reduces the modelled surface velocity by $<0.5 \%$ in the central region of the ice (Fig. 8). A maximum decrease of $2 \%$ is reached at the location of ephemeral grounding. Significant changes in velocity $(>5 \%$ in the center) are induced when the basal friction coefficient is $>10^{12} \mathrm{~Pa} \mathrm{~s} \mathrm{~m}^{-1}$, but such a large value is unlikely.

The ice rises in the ice shelf in front of Pine Island Glacier have a significant influence on the shelf's flow (Fig. 9). The main flow velocity (in the central region of fast-moving ice) typically decreases by $8 \%$ with the introduction of ice rises. Away from the ice rises, the decrease in velocity is proportional to the inverse of the distance to the ice rise as calculated by Thomas (1973). The decrease calculated away from the ice rise located at $74.85^{\circ} \mathrm{S}, 100.9^{\circ} \mathrm{W}$ (the one indicated by the second arrow pointing towards ice rises in Figure 4) follows approximately the curve $160 / r$, where $r$ is the distance from the ice rise.

We conclude from these experiments that despite the detectable influence of ephemeral grounding on the tidal deformation of an ice shelf, these features have no influence on the ice-shelf flow that would be of major significance to the overall stability and mass balance of the ice shelf. In the case of ice rises, it is good to notice that the model works as well and that it confirms what we expect, i.e. that they do exert a significant restraint on ice-shelf flow.

The importance of ephemeral grounding lies therefore in its potential to reveal subtle changes in ice-shelf thickness. As demonstrated in the case of the floating ice shelf in front of Thwaites Glacier, the evolution of areas of ephemeral grounding may reveal ongoing changes in ice-shelf thickness. If an ice shelf thickens, it becomes grounded over a larger area, and areas of ephemeral grounding may develop as the water column underneath the ice shelf decreases to within the tidal range. Conversely, when an ice shelf thins and retreats, areas of ephemeral grounding may remain for some period of time in the wake of the retreat. These retreats or advances may be quantitatively measured if InSAR observations are combined with tidal predictions.

\section{ACKNOWLEDGEMENTS}

This work was performed at the Jet Propulsion Laboratory, California Institute of Technology, under a contract with the NASA Polar Research Program. Funding at the University of
Chicago was provided by the U.S. National Science Foundation (OPP-9818622). We thank C. Werner for use of his SAR processor. We especially thank C. Hulbe who made numerous and very helpful comments on the text as well as on the figures, and an anonymous reviewer who also gave very constructive comments to improve the manuscript. Lastly, we would like to thank the Scientific Editor, R. Greve, for his thorough and expeditious handling of the paper.

\section{REFERENGES}

Bamber, J. L. and R. A. Bindschadler. 1997. An improved elevation dataset for climate and ice-sheet modelling: validation with satellite imagery. Ann. Glaciol., 25, 439-444.

Corr, H. F. J., D. G. Vaughan, C. S. M. Doake and A. Jenkins. 2000. Identification of an "ice-plain" at the grounding line of Pine Island Glacier, Antarctica. Filchner-Ronne Ice Shelf Programme Report 13, 8-12.

Crabtree, R. D. and C. S. M. Doake. 1982. Pine Island Glacier and its drainage basin: results from radio-echo sounding. Ann. Glaciol., 3, 65-70.

Ferrigno, J. G., R. S. Williams, Jr, C. E. Rosanova, B. K. Lucchitta and C. Swithinbank. 1998. Analysis of coastal change in Marie Byrd Land and Ellsworth Land, West Antarctica, using Landsat imagery. Ann. Glaciol., $27,33-40$.

Frolich, R. M. and C. S. M. Doake. 1988. Relative importance of lateral and vertical shear on Rutford Ice Stream, Antarctica. Ann. Glaciol., 11, 19-22.

Hartl, P., K.-H. Thiel, X. Wu, C. S. M. Doake and J. Sievers. 1994. Application of SAR interferometry with ERS-1 in the Antarctic. Earth Obs. Q., 43, $1-4$.

Holdsworth, G. 1969. Flexure of a floating ice tongue. J. Glaciol., 8(54), 385-397. Holdsworth, G. 1977. Tidal interaction with ice shelves. Ann. Géophys., 33(1/2), 133-146.

Hulbe, C. L., E. Rignot and D. R. MacAyeal. 1998. Comparison of ice-shelf creep flow simulations with ice-front motion of Filchner-Ronne Ice Shelf, Antarctica, detected by SAR interferometry. Ann. Glaciol., 27, 182-186.

Jenkins, A., D. G. Vaughan, S. S. Jacobs, H. H. Hellmer and J. R. Keys. 1997. Glaciological and oceanographic evidence of high melt rates beneath Pine Island Glacier, West Antarctica. F. Glaciol., 43(143), 114-121.

MacAyeal, D. R., R. A. Bindschadler and T. A. Scambos. 1995. Basal friction of Ice Stream E, West Antarctica. 7. Glaciol., 41(138), 247-262.

MacAyeal, D. R., V. Rommelaere, P. Huybrechts, C.L. Hulbe, J. Determann and C. Ritz. 1996. An ice-shelf model test based on the Ross Ice Shelf, Antarctica. Ann. Glaciol., 23, 46-51.

Merson, R. H. 1989. An AVHRR mosaic image of Antarctica. Int. F. Remote Sensing, 10(4-5), 669-674.

Rignot, E. 1996. Tidal motion, ice velocity and melt rate of Petermann Gletscher, Greenland, measured from radar interferometry. F. Glaciol., 42(142), 476-485.

Rignot, E. J. 1998a. Fast recession of a West Antarctic glacier. Science, $281(5376), 549-551$

Rignot, E. 1998b. Radar interferometry detection of hinge-line migration on Rutford Ice Stream and Carlson Inlet, Antarctica. Ann. Glaciol., 27, 25-32.

Rignot, E. In press. Evidence for rapid retreat and mass loss of Thwaites Glacier, West Antarctica. 7. Glaciol.

Rignot, E., L. Padman, D. R. MacAyeal and M. Schmeltz. 2000. Observation of ocean tides below the Filchner and Ronne Ice Shelves, Antarctica, using synthetic aperture radar interferometry: comparison with tide model predictions. 7. Geophys. Res., 105(C8), 19,615-19,630.

Robertson, R., L. Padman and G. D. Egbert. 1998. Tides in the Weddell Sea. In Jacobs, S. S. and R. F. Weiss, eds. Ocean, ice and atmosphere: interactions at the Antarctic continental margin. Washington, DC, American Geophysical Union, 341-369. (Antarctic Research Series 75.)

Smith, A. M. and C.S. M. Doake. 1994. Sea-bed depths at the mouth of Rutford Ice Stream, Antarctica. Ann. Glaciol., 20, 353-356.

Thomas, R. H. 1973. The creep of ice shelves: interpretation of observed behaviour. f. Glaciol., 12(64), 55-70. 